\title{
Article \\ Bibliometric Analysis of Scientific Production on Nursing Research in the Web of Science
}

\author{
Gregorio Jesús Alcalá-Albert ${ }^{1,2, * \mathbb{D}}$ and María Elena Parra-González ${ }^{2}$ (D) \\ 1 Quirónsalud Hospital Group (Madrid Area), 28223 Madrid, Spain \\ 2 Department of Research Methods and Diagnosis in Education, University of Granada, 51001 Ceuta, Spain; \\ elenaparra@ugr.es \\ * Correspondence: grealcalb@gmail.com
}

Citation: Alcalá-Albert, G.J.;

Parra-González, M.E. Bibliometric Analysis of Scientific Production on Nursing Research in the Web of Science. Educ. Sci. 2021, 11, 455. https://doi.org/10.3390/

educsci11090455

Academic Editor: Neil Gordon

Received: 23 July 2021

Accepted: 19 August 2021

Published: 24 August 2021

Publisher's Note: MDPI stays neutral with regard to jurisdictional claims in published maps and institutional affiliations.

Copyright: (c) 2021 by the authors. Licensee MDPI, Basel, Switzerland. This article is an open access article distributed under the terms and conditions of the Creative Commons Attribution (CC BY) license (https:// creativecommons.org/licenses/by/ $4.0 /)$.

\begin{abstract}
The fundamental pillars of nursing science-nursing care, management, and teaching and research-are in constant evolution. The adaptation of Spanish nursing to the European Higher Education Area has promoted nursing research. Over the past few years, several institutions have made official statements concerning the difficulty of finding teaching staff for university nursing degrees. This is closely linked to the production of research, given that minimum criteria must be met for university teacher accreditation. The goal of this study is to analyze scientific production in nursing, nursing research and teaching in The Web of Science in order to establish how this is progressing and to gain further insight into the field of academic nursing. A total of 34,497 documents were analyzed using the Bibliometrix software version 4.1.0. The results reveal an increase in nursing research over time. Most of this is published in English and mainly focuses on specific nursing areas, such as oncology or psychiatry. Spain occupies the eighth place worldwide in nursing research. In spite of this position, the data suggest that other factors are blocking the accreditation of university teachers of nursing in Spain. They also reflect the need to encourage nursing research in this setting in the future.
\end{abstract}

Keywords: bibliometric analysis; scientific production; nursing; nurse; research; teaching; health sciences

\section{Introduction}

The term "statistical bibliography" was introduced for the first time by Hulme [1] who referred to it as the illustration of scientific and technological processes by the computation of documents. This concept was forgotten until twenty years later when Gossnell [2,3] applied it in his thesis, after which it was next used by Raisig [4]. Based on the four citations that referred to statistical bibliography, Pritchard [5] considered this denomination to be inadequate. Instead, he proposed coining a new term, bibliometry, that adapted better to his definition: the application of mathematics and statistics to literature and communication and for which Pritchard is regarded as the father of bibliometry.

The goal of bibliometry is to study statistical behavior over time and to analyze scientific activity from different angles. On the whole, it focuses on quantitative evaluation, although it is recommendable to accompany this with a sociometric analysis. These studies facilitate bibliographic standardization and organization and also reveal trends in the editorial process of journals, the classification of articles, main research topics, etc. Ultimately, they help to understand the activity of journals and, in this way, to improve the analysis and interpretation of the data [6].

Since this concept and its definition first emerged, its use has become accepted to measure scientific production in different publications and is now widespread among all areas of knowledge. Examples of this in the area of nursing include articles about bibliometrics such as the one by Železnik et al. [7], focused on scientific production between 
1976 and 2015 in the Journal of Advanced Nursing, or the one by Winters (2018) on higher education in nursing in MERCOSUR.

Although the concept of nursing appears to be clear among the scientific community, it is not so well understood by the general population, which is often unaware of the precise roles of nursing staff, or the nursing grades existing in each country. This organization of nursing staff into grades is closely linked with training and research, which, in turn, are related to scientific production.

Prior to the adaptation of Spanish nursing degrees to the European Higher Education Area, the system classified nursing studies into nursing diplomas (usually with a three-year academic course) and degrees (with a five- or six-year academic course) [8].

In Spain, nursing was first taught in the university in 1977 as the nursing diploma. During the nineteen-nineties, the University Reform Law (URL) created the university credit system, and the range of subjects taught expanded to include some that focused on scientific production. Despite the progression in nursing studies, from the first undergraduate courses to then include doctorate studies and eligibility for research grants, students first had to have a university degree in nursing, and many graduates from the diploma had to complete a complementary degree course.

The nursing degree (with an academic course of four years of duration) did not appear until 2007, when nursing studies were adapted to the requirements of the European Area for Higher Education. This meant that, after obtaining a university master's of at least sixty credits, students could access doctorate courses and be awarded research grants [9]. The university reform also modified the requirements for the teaching staff of university degrees, and at least $80 \%$ of the staff had to have earned a doctorate degree and be accredited by the National Quality Assessment and Accreditation Agency of Spain (ANECA).

Julio Fernandez, ex-president of the National Confederation of Spanish Deans (CNDE in Spanish), in a statement to the media in 2018, described the difficulty of acquiring accreditation to become a university lecturer in nursing, including the need to have a doctorate in the field [10]. He explained the negative effect this had on the discipline, given that this could result in some nursing subjects being taught by professionals from other areas, and expressed his concern about this situation in the near future.

In spite of significant advances in Spanish nursing over just a short period, the number of doctoral theses being read has declined, with a subsequent drop in scientific production [11]. During the academic year 2018-2019, a total of $1614 \mathrm{PhDs}$ were awarded in the area of Health and Social Sciences, of which only 39 belonged to the branches of nursing and patient care (Figure 1) [12].

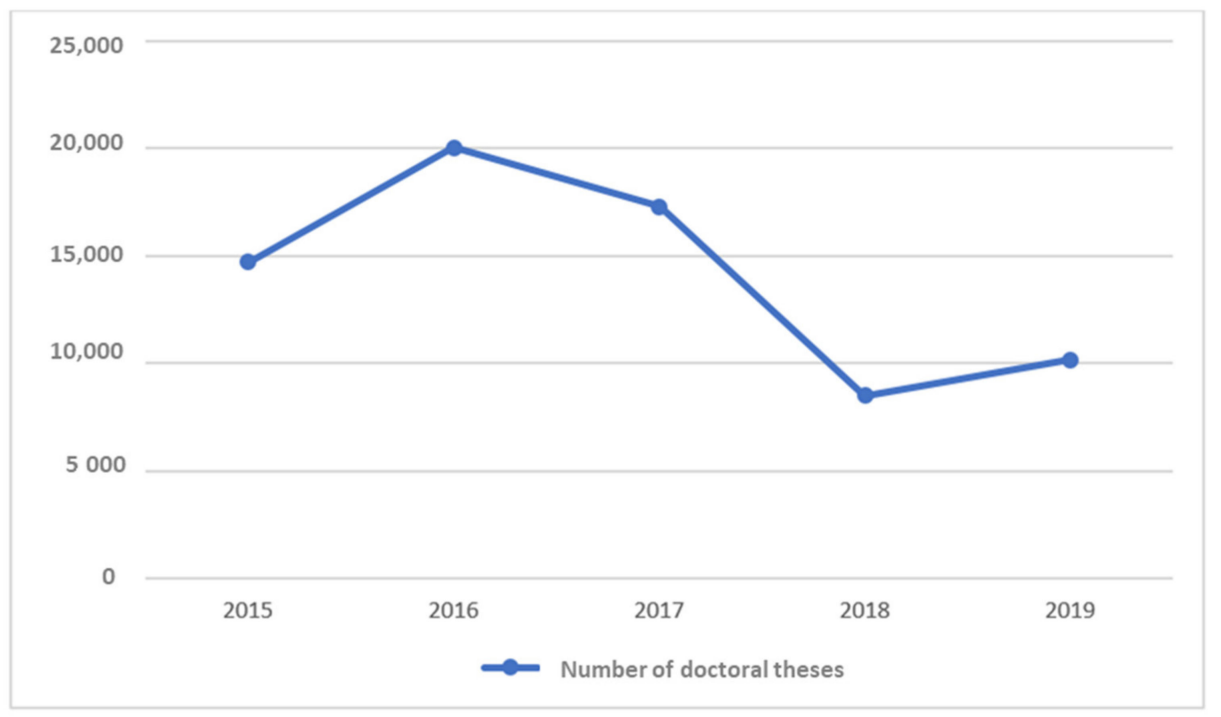

Figure 1. Evolution in the production of doctoral theses in Spain per year [12]. 
The entrenched belief in Spain that nurses are "doctors' assistants" could have hindered their professional development, given that the medical profession is central to research and scientific production. A study by Santana Padilla et al. [13] concluded that nurses still consider the need for infrastructure to promote research, as well as recognition by the institutions.

In other countries, where university nursing studies have been approached from a different angle, another pattern of development has emerged. For example, in the United States, where a master's in nursing first arose in 1929, back in 1960, the syllabuses already included subjects on research methodology [14]. In Spain, 27.4\% of graduate students matriculated in doctorate studies are foreigners.

The Spanish university system started to promote research during the process of its adaptation to the European Area for Higher Education by incorporating the requirement to produce a final year dissertation based on a research project. However, teaching in health sciences continues to follow a traditional approach, and university teaching staff must play an active role in detecting teaching needs and new methodologies, and by providing pedagogical guidance [15].

Modern nursing science has four essential functions-nursing care, management, teaching and research-with the latter two being closely linked.

Scientific production in a clinical role is based on the nursing discipline itself, given its assistential nature. Nursing research is therefore an essential and implicit component of this domain.

In science, it is essential to publish the results of research because it is commonly accepted that "what is not published has effectively not been done" [16]. Although bibliometric indicators are not the only way to measure scientific contribution, it is important to know them in order to understand how they function and their benefits, limitations and impact strategies in the scientific community [17].

In order to fully comprehend the Spanish nursing system and its future trajectory, it is important to determine and compare scientific production in nursing research at a global level. The ultimate objective is to ensure quality care and the continuity of nursing studies taught by the nurses themselves, who are the only ones who truly understand the science of nursing care.

The goal of this research is to conduct a bibliometric analysis to determine the true state of scientific production in nursing, nursing research and teaching.

\section{Materials and Methods}

This is a retrospective descriptive bibliometric study carried out according to the standard methodology used in this type of study [18].

A search was made for the descriptors "nursing", "nurse", "health sciences" and "research" in the categories "nursing", "education in educational disciplines", "education and educational research" and "multidisciplinary sciences" in The Web of Science (WoS) database, and more specifically in the document type "Article", from the first entry recorded until 2021. The connector "and" was used to increase the rigor of the search.

The scientific review criteria followed the protocols of the PRISMA matrix (Figure 2). This has been fully validated by the scientific community and is of recommended use [19].

After completing the search, a series of analytical techniques were applied including scientific mapping, quantification of bibliometric indicators (language, publication date, research field, document type, organizations, authors, sources, countries and citations).

Data were analyzed using the R-studio software with the Bibliometrix package, version 4.1.0.

The data search was conducted during June 2021, in a similar way to other studies of scientific rigor [20], and verifying compliance with the Price Law and Lotka's Law, and other impact indicators. 


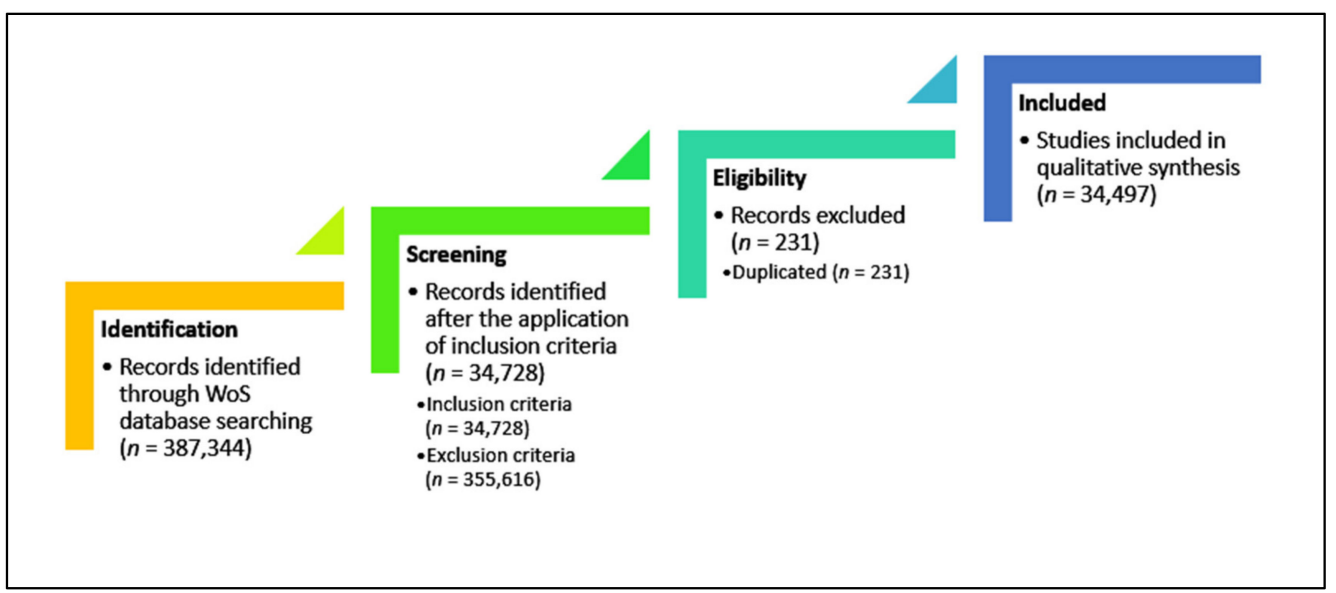

Figure 2. Diagram of the PRISMA statement.

\section{Results}

The initial search retrieved a total of 34,497 articles, none of which were excluded from the study. The earliest article was published in 1927 and the latest appeared in 2021. The articles proceed from 881 different sources, with a mean number of citations per document of 14.36 .

\subsection{Production Indicators}

\subsubsection{Diachronic Production}

On analyzing the references indexed in WoS, there was a significant growth in production over time of $8.6 \%$ annually, in accordance with the Price's Law (Figure 3) [21].

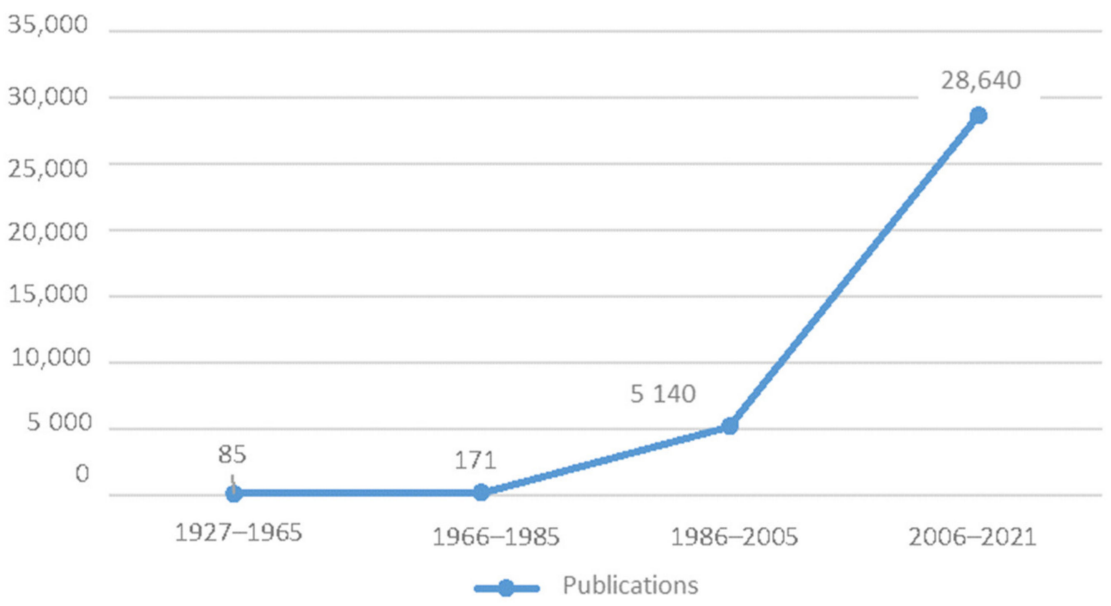

Figure 3. Graph showing compliance with the Price's Law.

\subsubsection{Individual Productivity}

Individual productivity was found to comply with Lotka's Law (1926) regarding the frequency of distribution, as shown in Figure 4, where a single author published 112 articles and 51,125 authors published one article. 


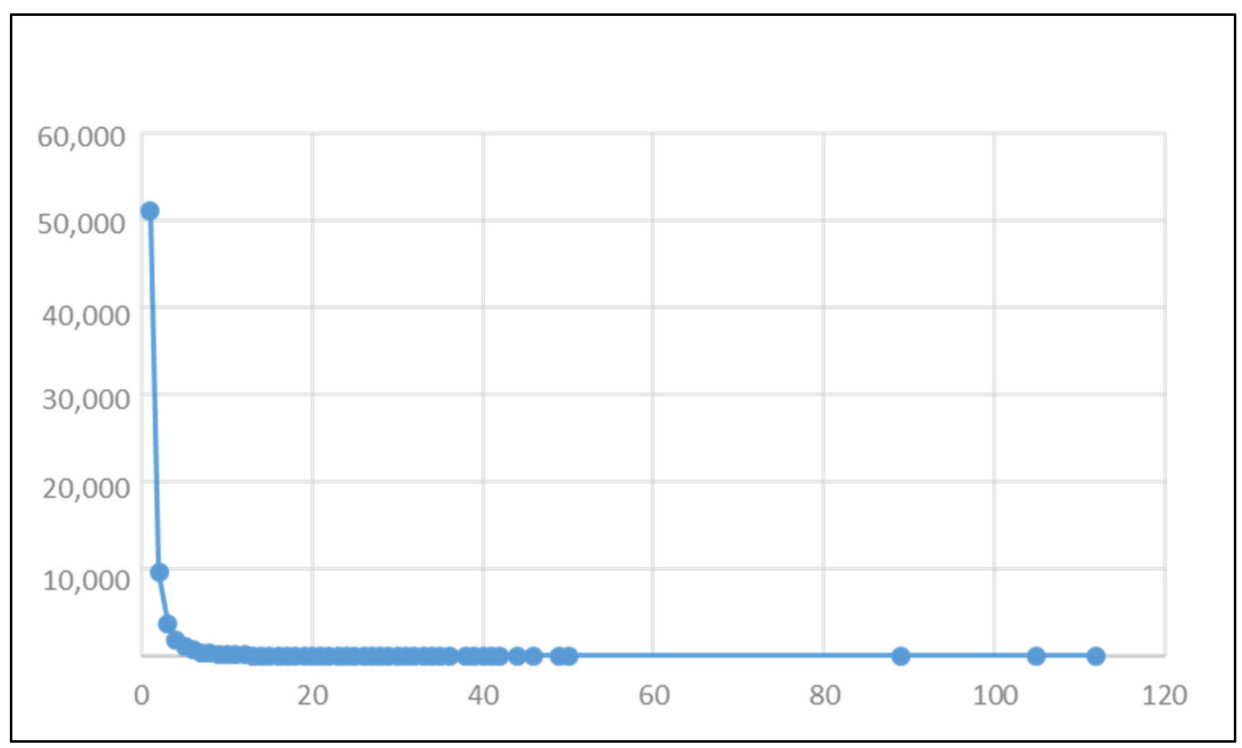

Figure 4. Graph representing Lotka's Law.

In the dependence analysis, a Pearson's coefficient of correlation of $r=-0.225$ was obtained. In other words, the correlation was negative (inversely proportional). The coefficient of determination R2 $=0.050$ revealed a weak correlation.

The most relevant authors are summarized in Table 1.

Table 1. List of the most relevant authors according to the number of published articles.

\begin{tabular}{cc}
\hline Author & Number of Articles \\
\hline Happell, B. & 112 \\
Jackson, D. & 105 \\
Leino-Kilpi, H. & 89 \\
Erdmann, AL. & 50 \\
Kim, S. & 49 \\
Usher, K. & 49 \\
Fitzpatrick, JJ. & 46 \\
Johnson, M. & 44 \\
Palese, A. & 44 \\
Suhonen, R. & 44 \\
Astedt-Kurki, P. & 42 \\
Van Hecke, A. & 41 \\
Cleary, M. & 40 \\
McKenna, L. & 40 \\
\hline
\end{tabular}

Collaborations among authors are shown in Figure 5.

\subsection{Scattering Indicators}

Scattering in the scientific literature tends to comply with Bradford's Law [22], which describes how the number of articles concentrated in a small number of journals (core) is similar to the number published in a large number of journals, grouped according to zones of greatest scattering [23].

The search retrieved a total of 881 sources distributed among a core and two zones of scattering, as shown in Figure 6. 


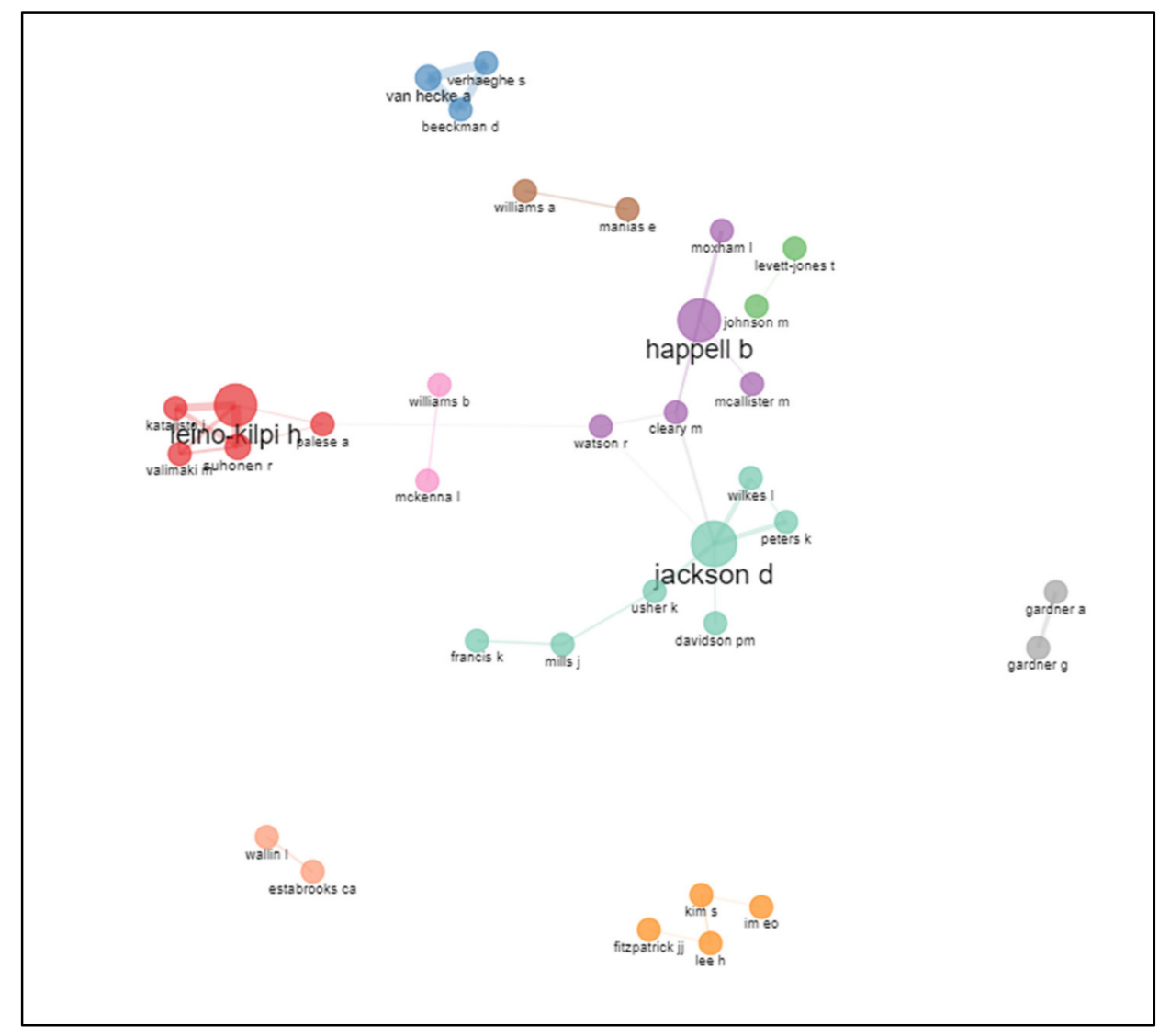

Figure 5. Graph showing collaborations among most relevant authors.

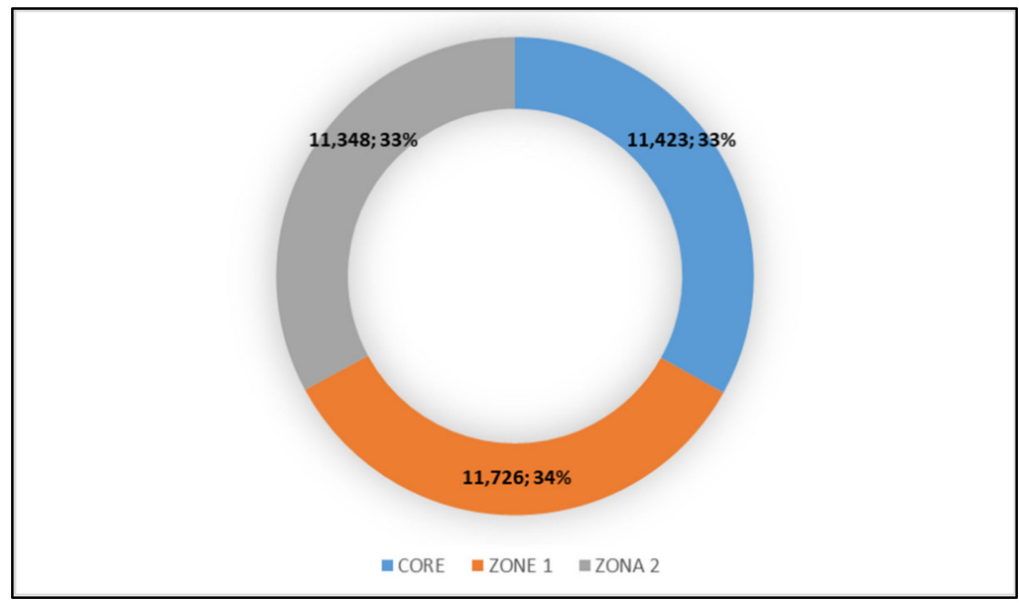

Figure 6. Distribution of production complying with Bradford's Law.

\subsection{Impact Indicators}

3.3.1. Production by Country and Language

Table 2 shows the countries in the study with the greatest scientific production, with the United States as the leading producer followed by Australia. Spain occupies the eighth position, with a total of 2119 articles. 
Table 2. Indicator of production per country.

\begin{tabular}{cc}
\hline Country & Number of Articles \\
\hline USA & 30,773 \\
Australia & 8495 \\
United Kingdom & 7107 \\
Brazil & 6119 \\
Canada & 5860 \\
China & 3682 \\
Sweden & 3011 \\
Spain & 2119 \\
Netherlands & 1645 \\
Turkey & 1606 \\
\hline
\end{tabular}

Regarding international collaborations, most of these occurred (266) between Australia and the United Kingdom. The distribution of collaborations is reflected in Figure 7. In Spain, most collaborations took place with Portugal (21), Chile and Finlandia (19), and the Netherlands (18).

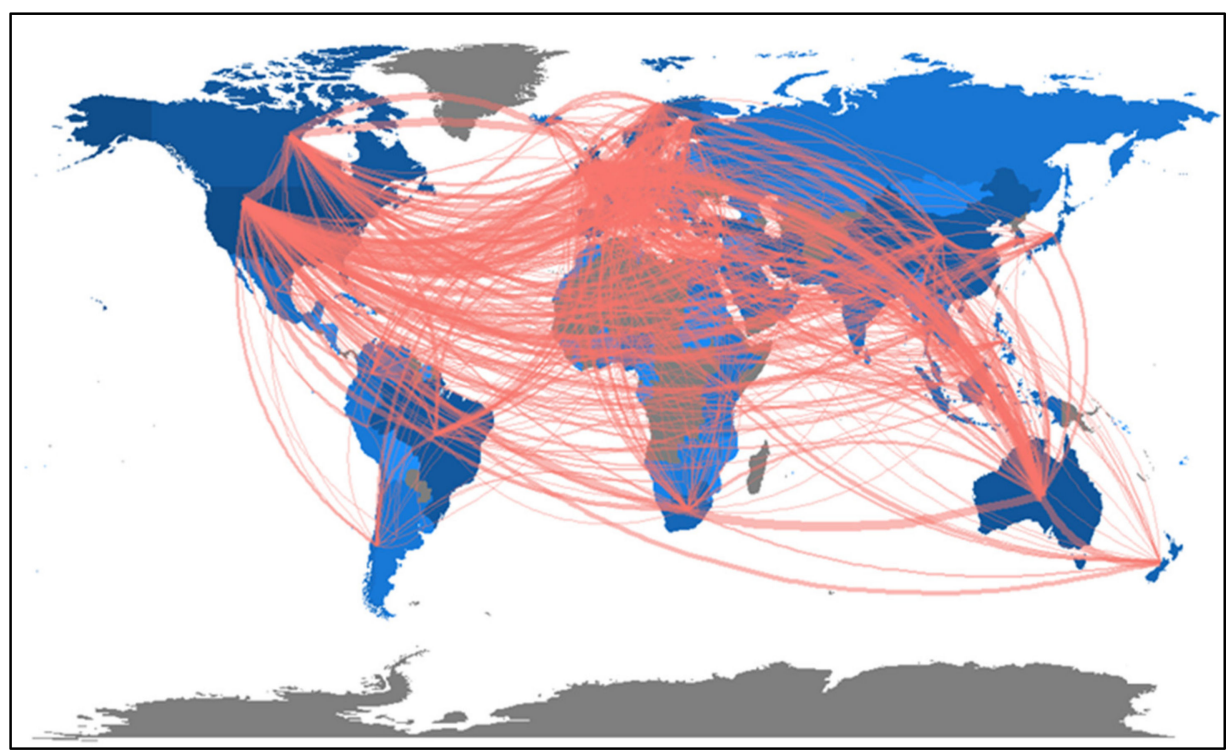

Figure 7. Map of the frequency of collaborations among countries.

Regarding the language of publication, most articles were published in English (95\%), followed by Portuguese (2\%). Production in Spanish amounted to $1 \%$ of articles, which is significant taking into account that only $2 \%$ correspond to the production in all other languages, including a total of seven (Korean, French, German, Turkish, Polish, Italian and Russian).

We can observe, therefore, how the Portuguese language has a large impact in scientific production in nursing [24], in agreement with our findings that Brazil was the fourth greatest producer.

According to Figure 8, together with the previously described results in Table 2, most authors publish in the English language even if this is not the language of their country of origin. 


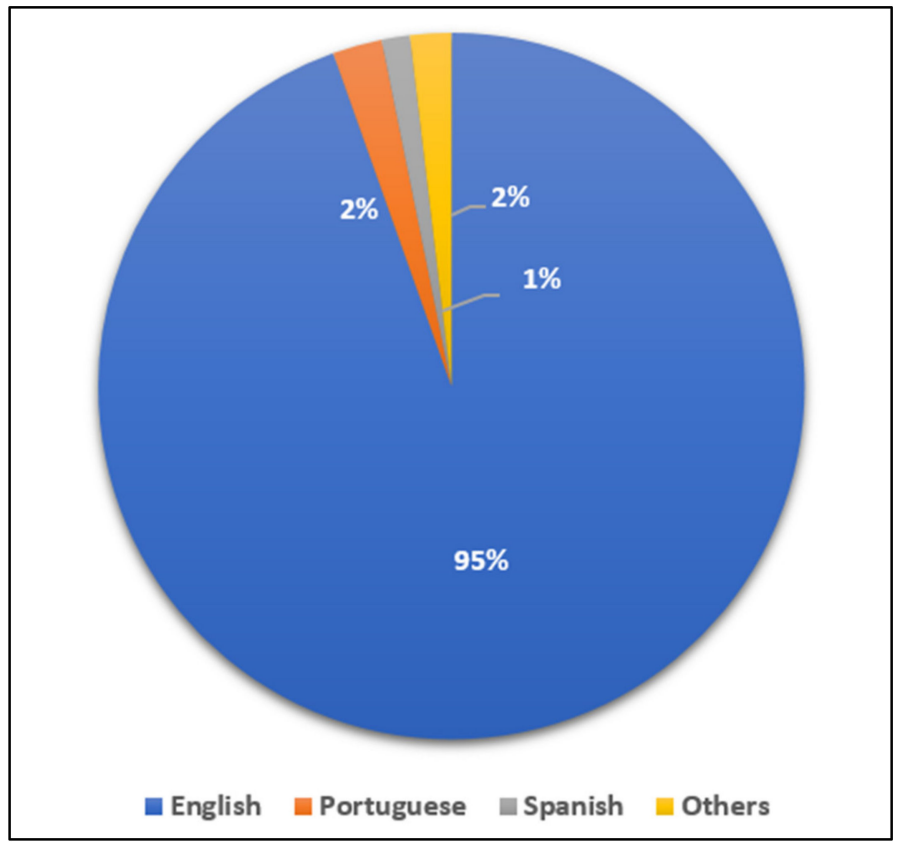

Figure 8. Graph showing scientific production in different languages.

\subsubsection{Bibliometric Map}

The network map shows the relationships among the key words. Figure 9 shows a group of four descriptors each of a different color. The font size in each case is proportional to the frequency of appearance and also to the number of connections with other descriptors [20].

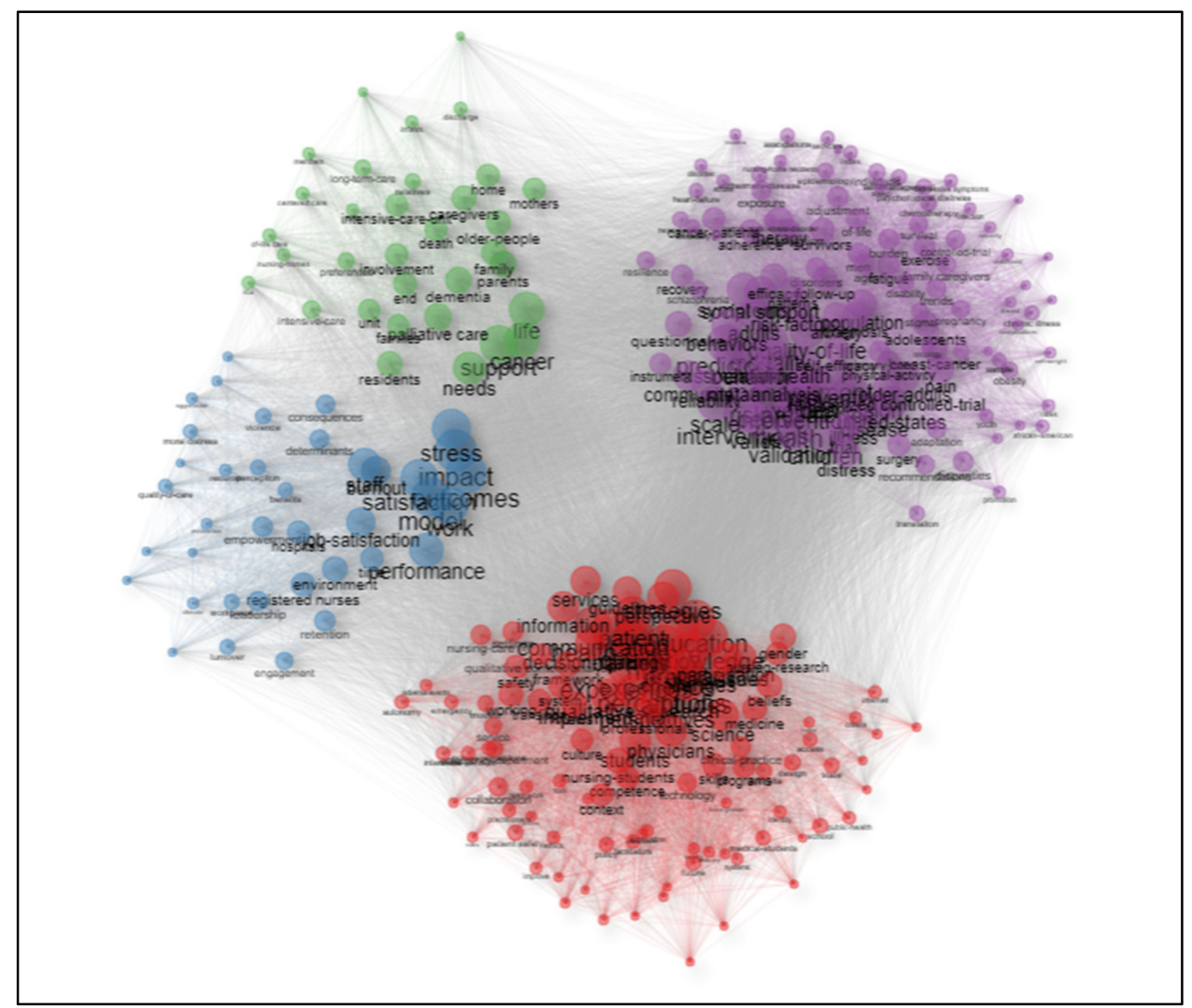

Figure 9. Bibliometric map. 
The green group is related to geriatrics and end-of-life needs and also parental roles, with a prominence of concepts such as "palliative care" and "the elderly". The blue group refers to topics associated with psychology and the social dimension, with a predominance of terms such as "impact" and "stress". The red group corresponds to nursing care and education and the terms "care" and "education", among others, are frequent. Finally, the purple group is related to quality-of-life and includes terms such as "risk" and "prevalence".

Relevance degree is reflected in the following graph (Figure 10).

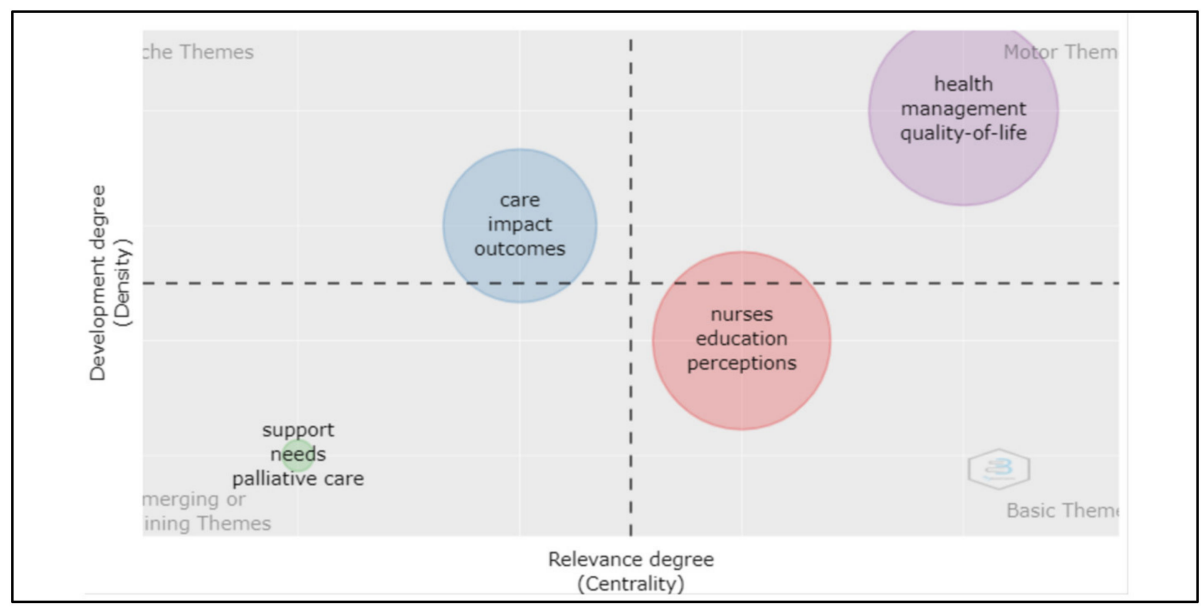

Figure 10. Relevance degree.

Changes in research area of the scientific production over time were measured by grouping per time interval in years, forming three basic groups. The first from 1927 (coinciding with the first publication) until 2010, the second from 2011 to 2016, and finally between 2017 and 2021. The results shown in Figure 11 are striking given that nursing, as a topic in itself, does not appear until the third period.

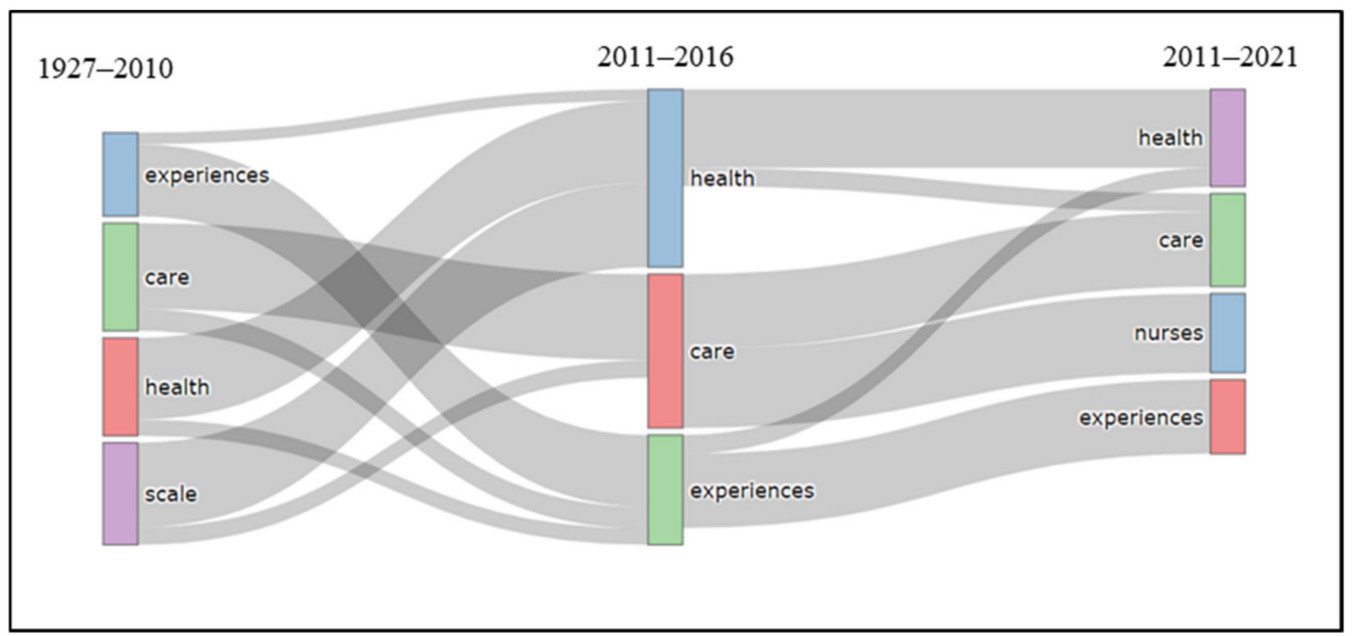

Figure 11. Evolution in research area over the study period from 1927-2021.

According to the $\mathrm{H}$-index (Table 3), the sources with the highest impact factors are the Journal of Advanced Nursing, the International Journal of Nursing Studies and the Journal of Clinical Nurse. 
Table 3. Study sources and their impact factors.

\begin{tabular}{cc}
\hline Source & Number of Articles \\
\hline Journal of advanced nursing & 115 \\
International journal of nursing studies & 68 \\
Journal of clinical nursing & 68 \\
Oncology nursing forum & 58 \\
Nurse education today & 53 \\
Nursing research & 48 \\
Scandinavian journal of caring sciences & 45 \\
Journal of nursing \& health & 44 \\
Research in nursing \& health & 44 \\
Cancer nursing & 42 \\
Academic medicine & 41 \\
Journal of nursing administration & 41 \\
PloS one & 41 \\
\hline
\end{tabular}

\section{Discussion}

Addressing the matter in question, scientific production is found to increase exponentially worldwide. This is in agreement with the results of previous studies, such as the one of Gregorio-Chaviano et al. [25] conducted in Latin America, and others of broader scope, like the one published by Kokol et al. [26]. This latter study reported a positive growth in scientific production, especially in the more developed "wealthier" countries.

With regards to this observation, on analyzing the results obtained here regarding the countries with the greatest scientific production, we found evidence of ones with a low GDP per capita in high positions of scientific production (Table 4). This reflects a lack of any clear link between the economy and scientific production in this subject area, and instead an investment of assets by the governments in these countries, or the interest of their scientific communities.

Table 4. Countries with the greatest scientific production in the study in relation to the GDP per capita of each one in 2020 (Diario Expansion) [27].

\begin{tabular}{cc}
\hline Country & GDP per Capita 2020 \\
\hline USA & $55,806 €$ \\
Australia & $46,281 €$ \\
United Kingdom & $35,418 €$ \\
Brazil & $6013 €$ \\
Canada & $37,919 €$ \\
China & $9215 €$ \\
Sweden & $45,850 €$ \\
Spain & $23,690 €$ \\
Netherlands & $45,870 €$ \\
Turkey & $7520 €$ \\
\hline
\end{tabular}

In a study by Zhu et al. [28], the most common areas focused on by nursing research were oncology and psychiatry. Moreover, in the same line as the results of Giménez and Prado [29], the greatest production in their search occurred in the Journal of Advanced Nursing, the International Journal of Nursing Studies and Nurse Education Today. Both results are in accordance with those obtained here, revealing a maintenance of this tendency in publications in this research area.

Claims such as that made by Gutiérrez Cruz [30] describe prejudices in nursing based on the practical nature of this discipline and society's view of the nurse as a caregiver, undermining the value of the theoretical aspects and research in this profession, even when conducted by qualified nurse professionals trained under this model.

Spanish research in this domain has progressed significantly, although mainly in an academic setting. However, some nurses in clinical practice play a key role in the 
development of research in care because these healthcare professionals know the problems that require investigative activity. In any case, nursing care and research should run parallel with each other [31].

With the global COVID-19 pandemic, nurses have been thrust into the public eye as care givers, and numerous articles have been published in an attempt to bring the pandemic to an end. However, the bibliometric study by Oh and Kim [32] found very few original articles on nursing related to COVID-19. Presumably, therefore, this new situation has not given rise to an increased interest for research in nursing, or, even more likely, nurses have had to focus their attention exclusively on patient care.

The nurse-to-patient ratio in each of the different healthcare services can be calculated using instruments such as the NEMS or NAS scale [33].

Following on from this, in countries belonging to the Organization for Economic Cooperation and Development (OECD), the mean ratio of nurses to 1000 patients is 8.8 [34], corresponding to a high care burden, so these professionals would probably have little time to dedicate to research.

Studies such as the one by Barrios et al. [35] report a high care burden resulting in stress and Burnout Syndrome with negative repercussions on work performance.

Research criteria, access to research and the link between research and the teaching activity vary among countries.

The year 2020 was designated International Year of the Nurse and Midwife through the Nursing Now movement in order to raise the profile of the professional nurse. Cristina Monforte, President of the Committee of Deans of Nursing Faculties in Spain, together with Florentino Pérez, President of the General Nursing Council in Spain, in an interview for the newspaper Acta Sanitaria insisted on the decline in nurse lecturers owing to their difficulty to obtain accreditation by the National Quality Assessment and Accreditation Agency of Spain (ANECA in Spanish), in addition to the low salaries [36].

We find ourselves at a tipping point that could complicate the future of teaching in this profession, making it difficult to replace retired nursing teachers in the short-term and impossible to find recruitments to cover for incidences.

According to the ANECA, to obtain the most basic form of accreditation as a university teacher, the first essential requirement is that the candidate must have earned a doctorate. They are then evaluated according to a series of merits, including research experience, teaching experience, academic training and others. At the least demanding scale of accreditation, at least five publications are required from journals positioned in the top two-thirds of their specialty in the Science Citation Index, excluding reviews or descriptions of case studies [37].

This situation is different in other countries, where teaching abilities are given more importance than research skills when awarding teaching posts to candidates.

It is recommendable to determine the interest in research among nursing students in training and how this relates to the teaching methodology. It is also necessary to improve working conditions and nurse staffing ratios. Employee institutions should unify international criteria to access research and teaching in order to promote research in nursing as an independent discipline.

\section{Conclusions}

The importance of nursing as the science of caring in clinical processes has been demonstrated throughout the history and evolution of this profession worldwide. Quality nursing care is beneficial to a patient's clinical condition and makes a positive contribution to the health service.

Some countries relegate nursing to the status of a purely practical-caring science, undermining the need for a theoretical basis and for research in this domain. The transmission of knowledge by teachers of nursing (even in practical clinical nurse training in hospitals), by nurses who have themselves been trained by a traditional approach, has resulted in 
this situation being passed on to new generations of nurses, who are receiving inadequate teaching with a limited focus on research.

Healthcare authorities and teaching professionals must review and adapt the number of teaching hours, study programs and methodologies in nursing research in graduate and postgraduate nursing degrees in order to encourage an interest in research among nurses.

Scientific production has been increasing exponentially over time but is still insufficient in Spain. In spite of a high international classification in this country, research in nursing lags behind other disciplines. This situation is endangering the future of the profession, owing to the difficulty to obtain accreditation by ANECA to teach nursing at the university level. In the future, a possible solution to this situation could result in teachers from other disciplines having to teach nursing subjects.

The requirements to teach nursing at university differ among countries. Within the European Higher Education Area, although common criteria have been established, these are more difficult to meet in some countries than others because of the difference in scientific production from one country to the next. For this reason, accreditation criteria required to be a university teacher should be adapted to each country.

Practicing clinical nurses play a key role in nursing research and in the interest in research shown by newly graduated nurses. Undergraduate nurses receive many hours of training to mentor them in clinical practice. A knowledge of recent scientific production and of new developments in the discipline would be beneficial to clinical practice. It is therefore necessary for healthcare employers and the authorities to encourage and promote nursing research among qualified professionals working in a clinical setting, as a way to convey this knowledge to the students, and also to serve as an example.

In their daily work, practicing clinical nurses have a high care burden and level of responsibility, and the nurse-to-patient ratio in centers is frequently lower than that recommended for a given medical specialty. As a result, these professionals suffer from a high level of Burnout Syndrome and work-related stress. This has a direct effect on research as nurses have little available time to dedicate to it. This situation could be improved by an effective management of nurse-to-patient ratios.

In Spain, there are very few clinical nurse researchers with work contracts that contemplate time for carrying out their clinical activity and also time to dedicate to research. Officially recognized mixed profiles for nurses that include both their assistential and investigative roles are required to promote scientific production in hospitals.

On the other hand, nurses should be remunerated or compensated in some way for research activity in order to encourage scientific production in this domain, thus reducing the disparity with other disciplines.

Ultimately, employers of healthcare professionals and institutions alike should work to promote nursing science. This can be done by implementing policies in each country to leave behind the conventional concept of the practicing nurse and to make way for a modern scientific nursing of quality. It is important that they provide the means to achieve this given the positive repercussions this would have on the health service.

Author Contributions: G.J.A.-A.: conceptualization, methodology, software, formal analysis, investigation, data curation, writing-original draft preparation, writing—review and editing. M.E.P.-G.: methodology, software, formal analysis, investigation, data curation, writing-review and editing, visualization, supervision. All authors have read and agreed to the published version of the manuscript.

Funding: This research received no external funding.

Conflicts of Interest: The authors declare no conflict of interest.

\section{References}

1. Hall, H.; Hulme, E.W. Statistical bibliography in relation to the growth of modern civilization. Economica 1923, 9, 266. [CrossRef]

2. Gosnell, C.F. The Rate of Obsolescence in College Library Book Collections, as Determined by an Analysis of Three Select Lists of Books for College Libraries; School of Education; New York University: New York, NY, USA, 1943. 
3. Gosnell, C.F. Obsolescence of books in college libraries. Coll. Res. Libr. 1944, 5, 115-125. [CrossRef]

4. Raisig, L.M. Statistical bibliography in the health sciences. Bull. Med. Libr. Assoc. 1962, 50, 450-461. [PubMed]

5. Pritchard, A. Statistical bibliography or bibliometrics. J. Doc. 1969, 25, 348-349.

6. Velázquez López, D.; Robledillo Colmenares, A.; Mangas Gallardo, I.; Veiga-Cabo, J.; Maqueda Blasco, J. Análisis bibliométrico de la revista Medicina y Seguridad del Trabajo durante el periodo 2007-2012. Med. Segur. Trab. 2013, 59, 383-392. [CrossRef]

7. Železnik, D.; Blažun Vošner, H.; Kokol, P. A bibliometric analysis of the Journal of Advanced Nursing, 1976-2015. J. Adv. Nurs. 2017, 73, 2407-2419. [CrossRef] [PubMed]

8. Gálvez, I.E. La política universitaria en la España democrática: Logros y carencias después de treinta años. Tend. Pedagog. 2006, 11, 207-222.

9. Canal, D.J. Evolución de la investigación en enfermería en España. Rev. ROL Enferm. 2017, 40, 414-416.

10. Nova, I. Para ser profesor titular en Enfermería te piden sangre de dragón. In Redacción Médica; Sanitaria Dos Mil: Madrid, Spain, 2018.

11. Ministerio de Ciencia, Innovación y Universidades. Infografía Tesis Doctorales 2018 [Internet]. Gobierno de España. 2018 Available online: https:/ / www.educacionyfp.gob.es/dam/jcr:2acffe7e-bac6-4613-a581-c2f8b438d320/infografia-tesis-doctorales2018.pdf (accessed on 19 July 2021).

12. Ministerio de Universidades. Datos y cifras del Sistema Universitario Español. Publicación 2020-2021. [Internet]. Gobierno de España. 2021. Available online: https://www.universidades.gob.es/stfls/universidades/Estadisticas/ficheros/Datos_y_Cifras_ 2020-21.pdf (accessed on 19 July 2021).

13. Padilla, Y.S.; Santana, J.M.; Santana-Cabrera, L.; Adell, M.B. Percepción de la calidad de la investigación enfermera en un hospital público. J. Healthc. Qual. Res. 2018, 33, 157-169. [CrossRef]

14. Muñoz, M.S. Competencias en Práctica Clínica Basada en la Evidencia de las Enfermeras en España; Universidad Complutense de Madrid: Madrid, Spain, 2015.

15. Santelices, L.; Williams, C.; Soto, M.; Dougnac, A. Efecto del enfoque de autorregulación del aprendizaje en la enseñanza de conceptos científicos en estudiantes universitarios en ciencias de la salud. Rev. Med. Chile 2014, 142, 375-381. [CrossRef]

16. Castellanos, G.C. La importancia de publicar los resultados de Investigación. Rev. Fac. Ing. 2014, 23, 7-8.

17. Flores-Fernandez, C.; Aguilera-Eguia, R. Indicadores bibliométricos y su importancia en la investigación clínica. ¿Por qué conocerlos? Rev. Soc. Esp. Dolor. 2019, 26, 315-316. [CrossRef]

18. Guerrero, A.J.M. Estudio bibliométrico de la Producción Científica sobre la Inspección Educativa. REICE. Rev. Iberoam. Sobre Calid. Efic. Cambio Educ. 2019, 17, 23-24. [CrossRef]

19. Rondon-Jara, E. ¿Es necesaria utilizar la declaración PRISMA en Ciencias de la Salud? Rev. Cuba. Enferm. 2020, 36, 1-3.

20. Campos Soto, M.N.; Ramos Navas-Parejo, M.R.; Moreno Guerrero, A.J. Realidad virtual y motivación en el contexto educativo: Estudio bibliométrico de los últimos veinte años de Scopus. Alteridad Rev. Educ. 2020, 15, 47-60. [CrossRef]

21. Price, D. Little Science, Big Science; Columbia University Press: Chichester, NY, USA, 1963. [CrossRef]

22. Brookes, B.C. "Sources of information on specific subjects" by SC Bradford. J. Inf. Sci. 1985, 10, 173-175. [CrossRef]

23. Arguedas, A.M. Bibliometría. Bibl. Rev. Esc. Bibliotecol. Doc. Inf. 1990, 8, 1-11.

24. Álvarez, D.E. Producción Científica y Acceso de las Enfermeras y Enfermeros a la Información en América Latina; Bib Lascasas. 2010, p. 6. Available online: http:/ /index-f.com/lascasas/documentos/lc0564.php (accessed on 19 July 2021).

25. Gregorio-Chaviano, O.; Méndez-Rátiva, C.P.; Peralta González, M.J.; Frías Guzmán, M. Investigación colombiana en enfermería. Un análisis bibliométrico de su visibilidad en ISI WoS (2001-2013). Enferm. Glob. 2015, 14, 175. [CrossRef]

26. Kokol, P.; Železnik, D.; Završnik, J.; Vošner, H.B. Nursing research literature production in terms of the scope of country and health determinants: A bibliometric study. J. Nurs. Scholarsh. 2019, 51, 590-598. [CrossRef]

27. PIB-Producto Interior Bruto [Internet]. Expansion.com. Available online: https://datosmacro.expansion.com/pib (accessed on 19 July 2021).

28. Zhu, R.; Liu, M.; Su, Y.; Meng, X.; Han, S.; Duan, Z. A bibliometric analysis of publication of funded studies in nursing research from Web of Science, 2008-2018. J. Adv. Nurs. 2021, 77, 176-188. [CrossRef] [PubMed]

29. Giménez-Espert, M.D.C.; Prado-Gascó, V.J. Bibliometric analysis of six nursing journals from the Web of Science, 2012-2017. J. Adv. Nurs. 2019, 75, 543-554. [CrossRef] [PubMed]

30. Cruz, E.G. La importancia de la investigación y la publicación para la mejora del cuidado. CuidArte 2017, 6, 4-5. [CrossRef]

31. González-Chordá, V.M. Importancia de las enfermeras clínicas para la investigación en cuidados. RECIEN. Rev. Cient. Enferm. 2018, 16, 1-5. [CrossRef]

32. Oh, J.; Kim, A. A bibliometric analysis of COVID-19 research published in nursing journals. Sci. Ed. 2020, 7, 118-124. [CrossRef]

33. Bravo-Criado, C. Cómo calcular el ratio enfermera-paciente. Rev. Esp. Pediat. 2016, 72 (Suppl. 1), 83-87.

34. Crespo-Montero, R., Sr. Año Internacional de las Enfermeras y las Matronas. Enferm Nefrol. 2020, 23, 7-8. [CrossRef]

35. Araya, S.B.; Mantuliz, M.C.A.; Valenzuela Parada, V. Relación entre carga laboral y burnout en enfermeras de unidades de diálisis. Enferm Nefrol. 2012, 15, 46-55. [CrossRef]

36. Clever Consulting. Enfermería Denuncia la Desaparición de Profesores Enfermeros [Internet]. Actasanitaria.com. 2020. Available online: https:/ / www.actasanitaria.com/consejo-profesores-enfermeros/ (accessed on 19 July 2021).

37. Requisitos Previos para Solicitar la Evaluación [Internet]. Aneca.es. Available online: http://www.aneca.es/Programas-deevaluacion/Evaluacion-de-profesorado/PEP/Requisitos-previos-para-solicitar-la-evaluacion (accessed on 19 July 2021). 